\title{
ポート噴射エンジン用多孔スワールインジェクタによる 噴霧の微粒化に関する研究
}

\author{
吉村 一樹 ${ }^{* 1}$ ，安川 義人 ${ }^{* 1}$ ，石井 英二*1，小林 信章 ${ }^{* 2}$
}

\section{Spray atomization of multi-swirl injector for port fuel injection engine}

\author{
Kazuki YOSHIMURA ${ }^{* 1}$, Yoshihito YASUKAWA ${ }^{* 1}$, Eiji ISHII ${ }^{* 1}$ and Nobuaki KOBAYASHI ${ }^{* 2}$ \\ ${ }^{*}$ Hitachi, Ltd., Research and Development Group \\ 832-2 Horiguchi Hitachinaka-shi, Ibaraki 312-0034, Japan \\ ${ }^{{ }_{2}}$ Hitachi Automotive Systems, Ltd. \\ 1671-1 Kasukawa-cho, Isesaki-shi, Gunma 372-0023, Japan
}

Received 4 August 2015

\begin{abstract}
We have studied the spray atomization of a multi-swirl injector with three orifices. Hollow-cone spray interactions and the flow field inside the nozzle were investigated by experimental observations and numerical simulations. First, the effects of the spray interactions on the spray atomization were investigated by optically measuring the spray patterns and the Sauter mean diameter (SMD) using the laser diffraction. The spray patterns indicated that the sprays from each orifice interact under the orifices, and this interaction can be classified into two types: liquid-film collision and droplet collision. In the case of the liquid-film collision, the collided liquid films are supposed to merge and then break up into larger droplets. In comparison, droplet collisions have a small effect on the value of the SMD in our experiments. Second, numerical simulations were conducted to investigate the flow field inside the orifices. The simulation results showed that a liquid film was formed along the side wall of the orifice, and the liquid film of the three orifices was thinner than that of the single orifice. From the experiments conducted above, smaller SMD was measured in the case of three orifices with droplet collision. These facts imply that the droplet diameter is decreased in the case of the three orifices. Finally, we proposed a modified atomization model to calculate the mean droplet diameter of the hollow-cone spray from the film thickness and velocity at an orifice outlet. The film thickness and velocity were calculated by the internal nozzle flow simulation. Although the modified atomization model underestimates the SMD under the liquid-film collision condition, it agrees well with the measured SMD under the droplet collision condition.
\end{abstract}

Key words : Atomization, Gas-liquid two-phase flow, Injector, Numerical simulation, Swirling flow

\section{1. 緒 言}

近年，自動車用ガソリンエンジンの排気性能向上，然費の改善が市場課題となっており，その解決策の一つと して然料を噴霧としてエンジン内へ供給する装置であるインジェクタの性能向上が求められている. 吸気ポート にインジェクタを備えた Port Fuel Injection(PFI)エンジンでは，燃料の吸気ポート壁面への付着が HC(hydrocarbon) 発生の要因となっており(Samenfink et al., 2003), 然料が壁面へ付着しないように噴霧形状を制御する必要がある. また，燃焼効率を向上させて燃料消費量を低減するために，噴霧を微粒化して燃料と空気を混合しやすくする必 要がある。

例えば,インジェクタの先端に複数の噴孔を持つ多孔ノズルインジェクタは, 単孔のインジェクタと比較して,

No.15-00433 [DOI:10.1299/transjsme.15-00433], J-STAGE Advance Publication date : 5 November, 2015

*1 正員, (株)日立製作所 研究開発グループ (テ312-0034 茨城県ひたちなか市堀口 832-2)

*2 日立オートモティブシステムズ(株)（テ372-0023 群馬県伊勢崎市粕川町 1671-1）

E-mail of corresponding author: kazuki.yoshimura.ox@hitachi.com 
各噴孔からの噴霧を組み合わせることにより噴霧形状の制御性に優れ，燃料の壁面付着を低減でき，近年の自動 車用燃料インジェクタの主流となっている(Tani et al., 1999). また，燃料の流路に旋回室を持つことを特徵とする スワールインジェクタは, 旋回室内で生じる旋回流の遠心力を利用して噴孔内で薄い燃料の液膜を形成して微細 な液滴へ分裂しやすくし，噴射後は遠心力により中空円錐状の噴霧を拡散させることで，微粒化を促進させるこ とが可能である. スワールインジェクタは特に微粒化性能に優れることから，これまで多く研究されているが (Rizk and Lefebvre, 1985; Inamura et al., 2003), 微粒化を促進するために噴孔内の遠心力を強くすると噴霧が広がり やすく，微粒化と噴霧形状（噴霧角）制御の両立が難しいという課題がある。そこで筆者らは多孔ノズルインジ ェクタの噴霧制御性とスワールインジェクタの微粒化性能を両立すべく, スワールインジェクタの噴孔数を増や した多孔スワールインジェクタを研究している. 多孔スワールインジェクタの先行研究としては, 例えば, 多孔 プレートと遮蔽板を用いることで流れに旋回を付与し，各噴孔で中空円錐状の噴霧を形成することで，微粒化を 促進する方法が研究されている(谷他, 2002; Tani et al., 2006).

本研究で用いた多孔スワールインジェクタは, 図 1 (a)に示すように, インジェクタ先端に設置されたノズルプ レートに，燃料が旋回寸るための旋回室と，燃料を噴射するための噴孔を複数持つことが特徵である．これまで の研究(Yasukawa and Okamoto, 2007; Yasukawa et al., 2014)で, 多孔スワールインジェクタは従来の多孔ノズルイン ジェクタと比較して, 微粒化性能を向上し, ペネトレーションを短くすることが可能であり, PFI エンジンの試 験により排気性能と燃費が向上することを確認している.

多孔スワールインジェクタでは, 図 1 (b)に示すように各噴孔からの噴霧同士が干渉し, 微粒化性能に影響する ことが予想されるが，噴霧干渉が粒径に与える影響については十分検討されていない，そこで本研究では，実験 及び数值解析から, 多孔スワールインジェクタ特有の噴霧微粒化現象について明らかにすることを目的とし, 以 下について検討した. (1)噴霧の可視化実験と, 平均粒径である Sauter mean diameter (SMD)の測定により, 噴霧干 渉時の噴霧の状態（液膜の状態，または液滴の状態）が粒径に与える影響について検討した。(2)実験による測定 が困難なインジェクタ先端のノズル内部流れ場に関して, 気液二相流の数值解析を実施した。噴霧形状や粒径は 噴孔から噴射される際の流れ場によって決まるため, 特に噴孔出口面の流れ場に着目し, 多孔化が微粒化へ与え る影響について検討した. (3)上記の実験と数值解析から得られた知見を用いて, ノズル内部流れの数值解析によ り噴霧の平均粒径を簡易に算出する手法を構築し, 妥当性を検証した. スワールインジェクタの粒径を予測する 方法としては，実験式による算出（小林，1953）が最も容易だが，ノズル形状によっては粒径予測誤差が大きい という問題がある. 近年では Large Eddy Simulation や粒子法といった数值解析手法を用いてノズル内部から噴霧 まで解析し，粒径を算出することが可能である (Befrui and D’Onofrio, 2014; Ishii et al., 2011). しかし， 1 ケースの 解析時間が長いことから，ノズル設計時にはより短時間で粒径を予測する手法が求められている. 本研究の粒径 算出手法では，ノズル下流の噴霧を含めた数值解析を実施することなく，ノズル内部のみの数值解析により，短 時間で精度よく平均粒径を算出することかでき, 工業的に非常に有用である.

(a)

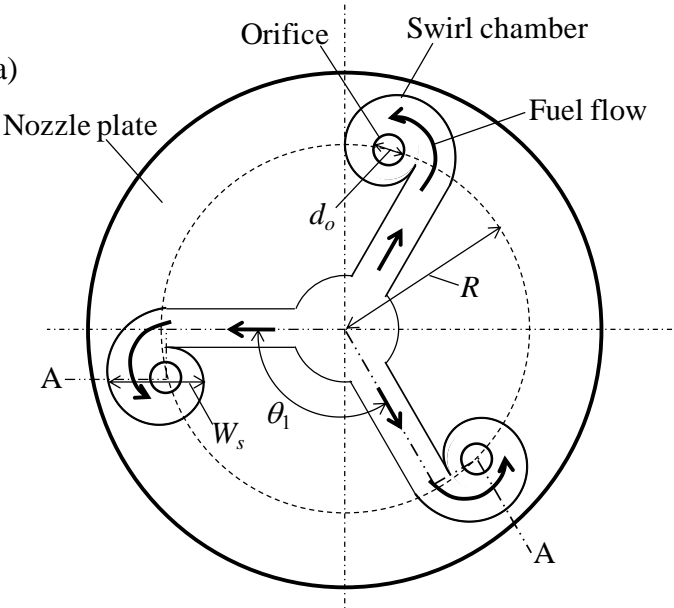

(b) Nozzle body

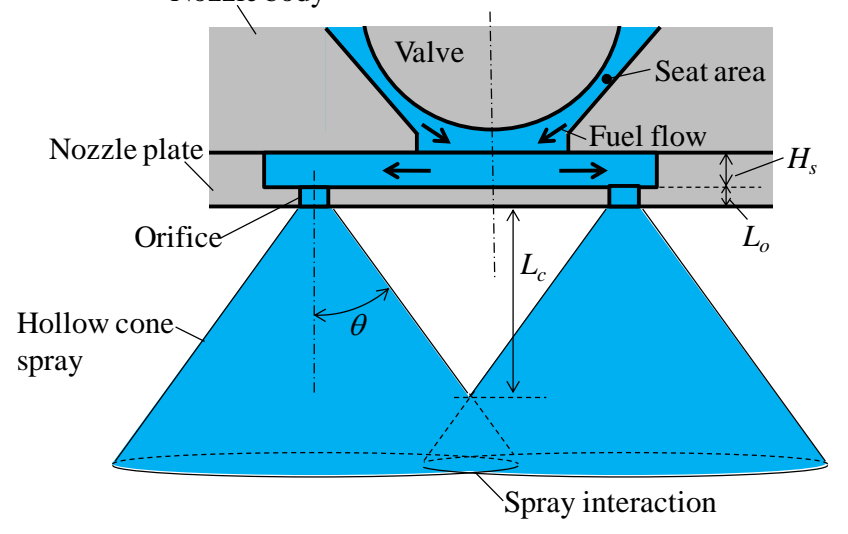

Fig. 1 Schematics of multi-swirl injector. (a) Nozzle plate with three swirl chambers and orifices. (b) Section A-A of injector tip. The fuel is sprayed from the orifice, and hollow cone sprays interact with each other under the orifices. 


\section{2. 噴霧干渉が粒径に与える影響の検討}

\section{$2 \cdot 1$ 実験装置}

本研究では単孔もしくは 3 孔のノズルプレートを備えたインジェクタを用いて, 噴霧の撮影と SMD の測定を 行い，多孔スワールインジェクタの噴霧同士の干渉が粒径に与える影響について検討した. 使用したインジェク タのノズル仕様を表 1 に示す. 表中の記号は図 1 に示しており, 全て噴孔径で無次元化している. Orifice angle は噴孔の中心軸と弁体の中心軸がな寸角度である．単孔と 3 孔の旋回室と噴孔の寸法は同一とした．以下，単孔 のノズルプレートを「単孔ノズル」，3 孔のノズルプレートを「3 孔ノズル」と記載する．噴霧測定は大気圧下で 行い，噴射差圧を $100 \mathrm{kPa}$ から $900 \mathrm{kPa}$ まで変化させた。

図 2 は噴霧撮影のための装置である. 本実験では大気開放下での実験のため，代替燃料としてガソリンと物性 は近いが引火しにくい Low Aromatic White Spirit (LAWS)を用いている. 長距離顕微鏡を備えた CCD カメラで噴霧 の拡大画像, CCD カメラのみを用いて噴霧の断面画像を撮影しており，撮影した画像は PCに送られる．燃料の 噴射，撮影，光源として用いるYAG レーザー照射のトリガーは PCで制御している.

図 3 はSMD 測定のための装置である. 燃料にはガソリンを用いている. SMD は次式のように, 液滴の総体積 を総表面積で割ったもので定義される.

$$
\mathrm{SMD}=\frac{\sum_{i} n_{i} d_{i}^{3}}{\sum_{i} n_{i} d_{i}^{2}}
$$

$d$ は液滴径， $n$ はその液滴径で測定された液滴の個数である. SMD の測定にはレーザー回折による測定装置 (MALVERN, SPRAYTEC RTS5000)を用いている．SMDの測定位置はインジェクタの先端から $20 \mathrm{~mm}$ 下流，レー ザーの照射位置は噴霧の中心としている.

Table 1 Nozzle specifications. Length values are non-dimensionalized by orifice diameter.

\begin{tabular}{|c|c|c|c|}
\hline Orifice diameter $\left(d_{o}\right)$ & 1 & Height of swirl chamber $\left(H_{s}\right)$ & 0.37 \\
\hline Orifice length $\left(L_{o}\right)$ & 0.3 & $\begin{array}{c}\text { Width of swirl chamber at center } \\
\text { of the orifice }\left(W_{s}\right)\end{array}$ & 1.8 \\
\hline Pitch circle diameter of orifices $(2 R)$ & 7.4 & Orifice angle [degree] & 0 \\
\hline
\end{tabular}

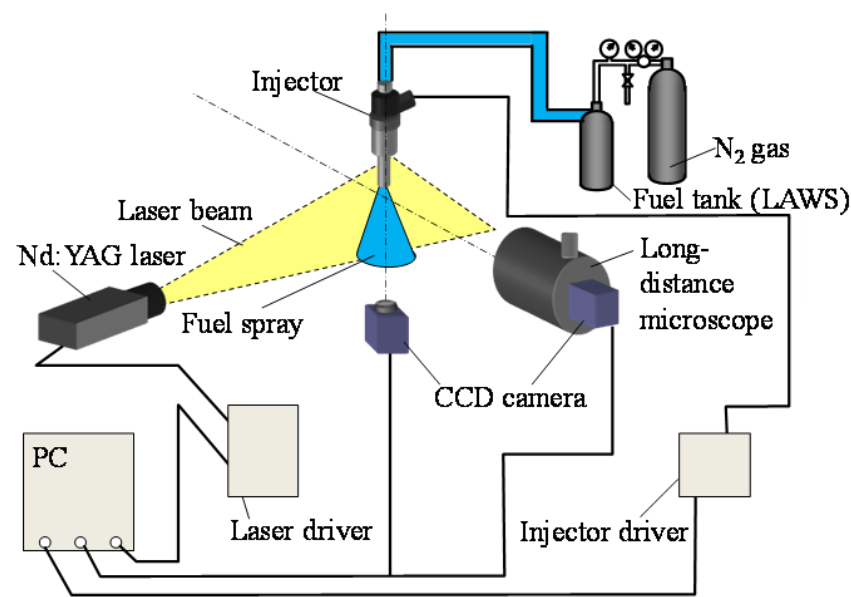

Fig. 2 Apparatus for taking spray images with CCD camera and long-distance microscope.

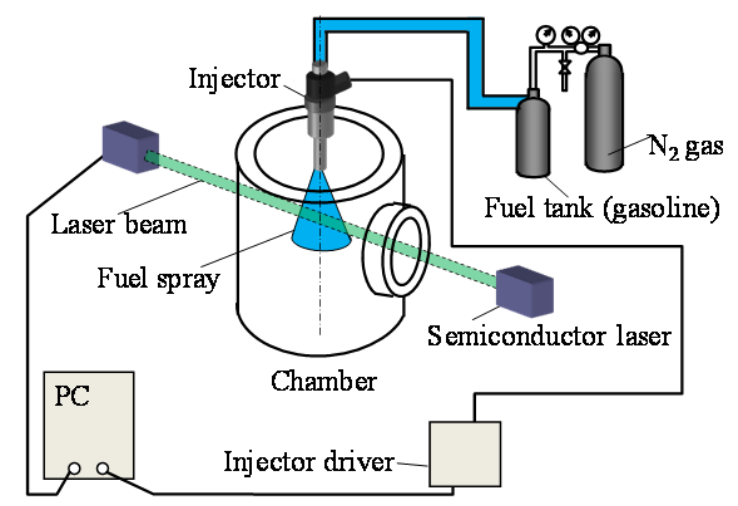

Fig. 3 Apparatus for measuring SMD.

\section{$2 \cdot 2$ 実験結果}

図 4 は単孔ノズル，図 5 は 3 孔ノズルの，噴孔出口近傍を拡大して撮影した噴霧画像である。画像は噴射開始 の信号を入力してから $4.75 \mathrm{~ms}$ 後, 弁体は完全に開いた状態で撮影している. 噴射差圧 $\Delta P_{\mathrm{inj}}$ を変化させて撮影し 
ているため，流量は噴射差圧の条件によって異なることに注意が必要である．図 4 より，いずれの噴射差圧の条 件においても噴孔直下では円錐状に噴霧を形成していることが分かる. $100 \mathrm{kPa}$ では液膜に穴があいた後に分裂し ており，200 kPa 以上では液膜が波うちながら分裂している．噴射差圧が高いほど液膜の波うつ周期は短く, 液滴 一分裂するまでの液膜長さも短くなっている。これは燃料の速度が大きくなるにつれ，気液界面の不安定性が増 大し，分裂が促進されたためである. 図 5 に示した 3 孔ノズルでは, いずれの噴射差圧においても各孔からの噴 霧は互いに干渉しており，100, 200, $300 \mathrm{kPa}$ では噴霧の中心部で液膜部分が干渉している様子が確認できる. 500 $\mathrm{kPa}$ 以上では干渉部分におけるカメラ側の液滴が白く写っているため, 干渉している部分の様子は明確ではない. これは噴霧干渉時にはすでに液膜の一部が液滴へと分裂しているためと予想される.

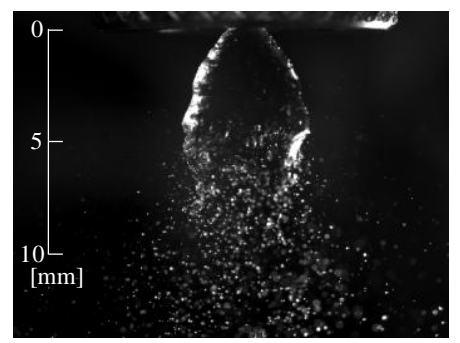

(a) $\Delta P_{\text {inj }}=100 \mathrm{kPa}$

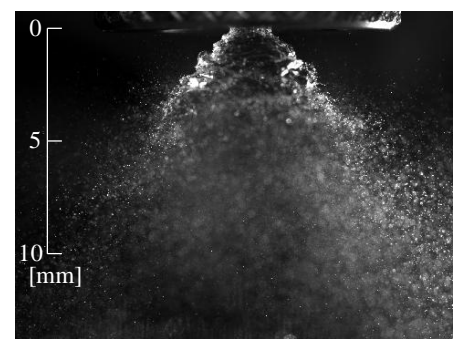

(d) $\Delta P_{\text {inj }}=500 \mathrm{kPa}$

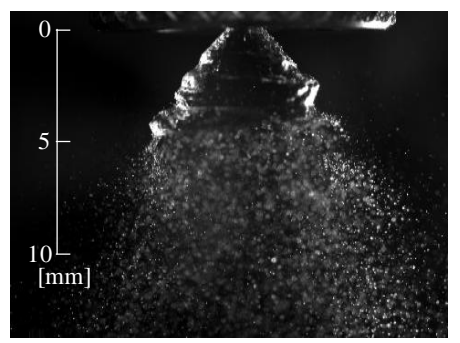

(b) $\Delta P_{\text {inj }}=200 \mathrm{kPa}$

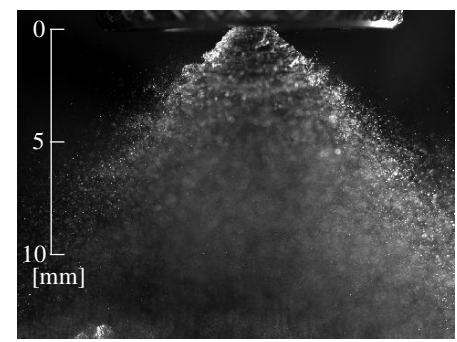

(e) $\Delta P_{\text {inj }}=800 \mathrm{kPa}$

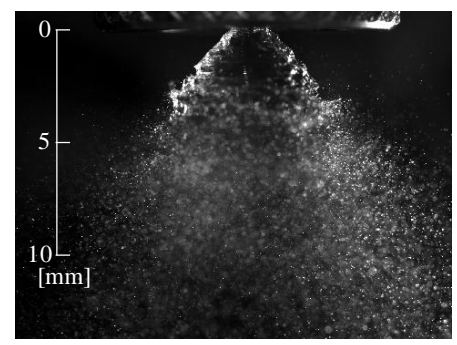

(c) $\Delta P_{\text {inj }}=300 \mathrm{kPa}$

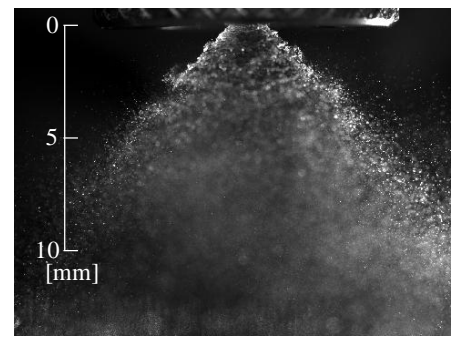

(f) $\Delta P_{\text {inj }}=900 \mathrm{kPa}$

Fig. 4 Images of spray from injector with the single orifice taken by long-distance microscope. The liquid film is formed under the nozzle and broke up into droplets. The liquid film length is shortened as the injection pressure increased.

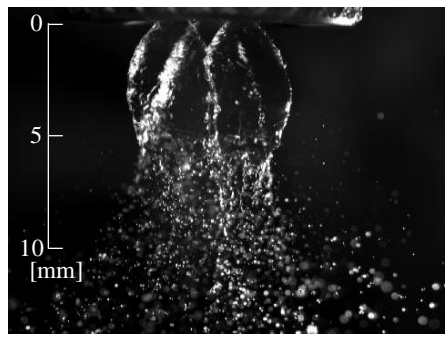

(a) $\Delta P_{\text {inj }}=100 \mathrm{kPa}$

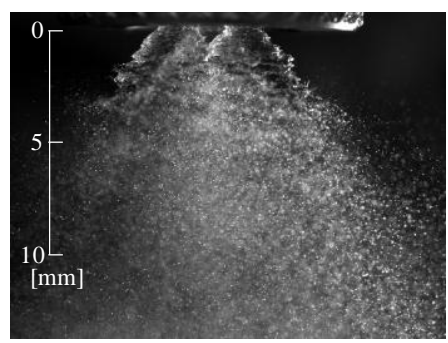

(d) $\Delta P_{\text {inj }}=500 \mathrm{kPa}$

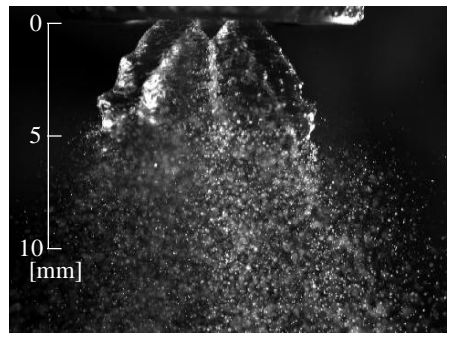

(b) $\Delta P_{\text {inj }}=200 \mathrm{kPa}$

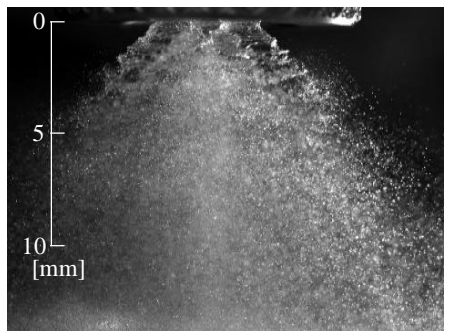

(e) $\Delta P_{\text {inj }}=800 \mathrm{kPa}$

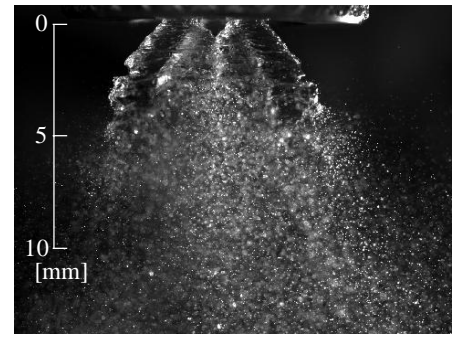

(c) $\Delta P_{\text {inj }}=300 \mathrm{kPa}$

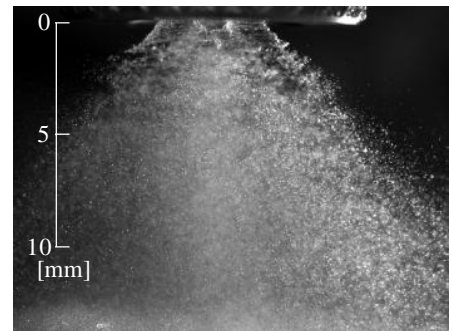

(f) $\Delta P_{\text {inj }}=900 \mathrm{kPa}$

Fig. 5 Images of spray from injector with the three orifices taken by long-distance microscope. The spray from each orifice interacts in every condition of injection pressure. In particular, liquid film collisions are seen between 100 and 300 $\mathrm{kPa}$. 
次に，噴霧干渉の様子を確認するために，噴孔真下から噴霧の断面を撮影した結果を図 6 に示す．画像は噴射 開始の信号を入力してから $4.75 \mathrm{~ms}$ 後, 弁体は完全に開いた状態で, 噴孔 $15 \mathrm{~mm}$ 下にシート状のレーザーを照射 して撮影している. 噴射差圧は $300 \mathrm{kPa}$ とした. 画像の右側には撮影した画像の視点における噴孔配置の模式図を 示している．模式図は噴孔配置を分かりやすくするために噴孔径と噴孔間距離を拡大して表示している. 図 6 (a) より, 単孔ノズルでは噴霧が中空になっている様子が分かる.一方で, 図 6 (b)の 3 孔ノズルでは, 各孔からの噴 霧は噴霧の干渉により中空になっていない，画像では Y 字状に噴霧が濃くなっている箇所があるが，各噴孔から の噴霧が互いに干渉しているためであると考えられる. 図中の点線の円印は単孔ノズルによる噴霧の広がりの外 径を表しており, 同じ径の円を 3 孔ノズル側にも描写している. 図より, 3 孔ノズルでは噴霧の広がりがやや小 さく見える.これは噴霧によって速度が誘起され,ベルヌーイの定理によりその領域では圧力が低下したことで, 各噴孔からの噴霧同士が引き付け合ったためと考えられる.

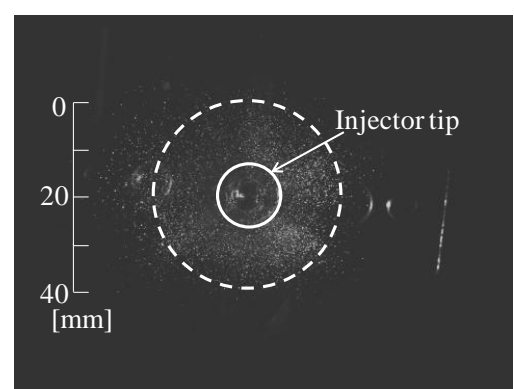

(a) Single orifice

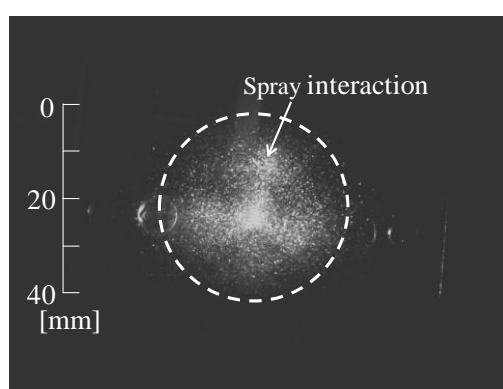

Injector tip

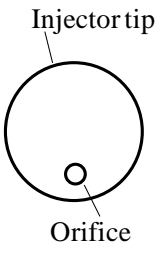

(b) Three orifices

Fig. 6 Images of cross-section of the sprays at $15 \mathrm{~mm}$ from the injector tip. In the single orifice, it is found that the hollow-cone spray is formed. In the three orifices, the spray interaction is observed as the concentrated area of fuel. The sprays of three orifices shrink due to the pressure drop in sprayed area comparing with spray of the single orifice.

図 7 は SMD に対する噴射差圧の影響を表している。横軸は噴射差圧，縦軸はSMD である．図 7 より，図 5 で液膜干渉が見られた噴射差圧(100 300 kPa)では 3 孔ノズルよりも単孔ノズルの SMD が小さく, 高圧になるに つれその差は小さくなっている．これは，上記の噴霧観察結果から，干渉時の噴霧の状態と関係があると考えら れる. 寸なわち, 液膜で干渉している低圧側では 3 孔ノズルの SMD が大きくなり, 液膜分裂後に干渉している 高圧側ではSMD の差は小さくなっている．また，図７(b)で示した噴射差圧の範囲では，単孔ノズルよりも 3 孔 ノズルの SMD が小さくなる傾向にある.この要因については 3.2 節で後述するが，3 孔ノズルの噴霧では噴孔内 で形成される液膜が薄くなったためと考えられる.

(a)

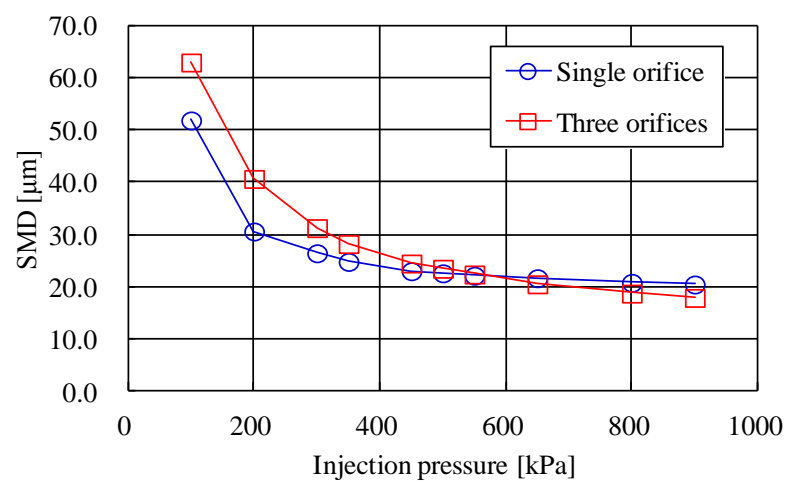

(b)

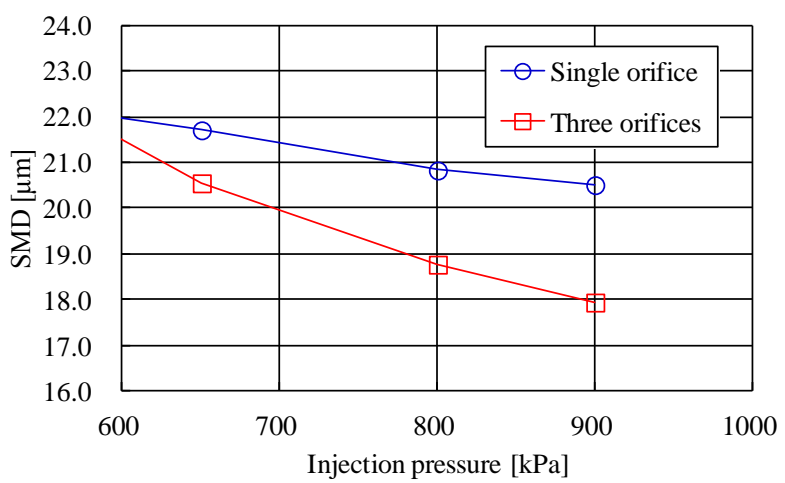

Fig. 7 Measured SMD as a function of injection pressure. (a) The single orifice and the three orifices are compared. (b) Enlarged view of Fig. 6 (a) in the range from 600 to $1000 \mathrm{kPa}$. The results show that the values of the three orifices are higher than those of the single orifice at a low injection pressure condition. It is considered that the SMD is related to spray interaction. 
上述のように噴霧干涉時の燃料の状態 (液膜か液滴か) が粒径に大きく影響していると考えられる. そのため, 液膜長さと噴霧の干渉位置について詳細に検討する必要がある. そこで図 1 で示した噴霧の干渉位置 $L_{\mathrm{c}}$ を次式で 定義する.

$$
L_{\mathrm{c}}=R \cdot \frac{\sin \left(\frac{\theta_{1}}{2}\right)}{\tan \theta}
$$

$R$ は同一平面上におけるノズルプレートの中心から噴孔の中心までの距離である． $\theta_{1}$ はノズルプレート上の噴孔 配置の角度であり, 本研究では $3 つ の$ 噴孔を等間隔に配置しているため $120^{\circ}$ となる， $\theta$ は噴霧の縁と噴孔の中心 軸がな寸角度であり，噴霧角の $1 / 2$ である。噴霧角 $2 \theta$ は画像から計測した值を用いた。

図 8 は単孔ノズル及び 3 孔ノズの液膜長さと,式(2)から算出した噴霧の干渉位置 $L_{\mathrm{c}}$ を比較したグラフである. 横軸は噴射差圧，縦軸は噴孔出口位置を基準とした液膜長さと，噴霧の干涉位置である．まず，液膜長さに関し て,噴射差圧が大きくなるにつれ液膜長さは短くなっていることが分かる. 単孔と 3 孔に大きな差は見られない. 次に, 液膜長さと噴霧の干渉位置 $L_{\mathrm{c}}$ を比較する. $500 \mathrm{kPa}$ までは液膜長さは干渉位置よりも大きい. $800 \mathrm{kPa}$ 以上 では液膜長さが干涉位置よりも小さくなっている，これらの結果は図 5 に示した噴霧の様子とおおよそ一致して いる.さらに，図 7 から 3 孔と単孔の SMD が同程度となる位置も $500 \mathrm{kPa}$ であることが分かる.
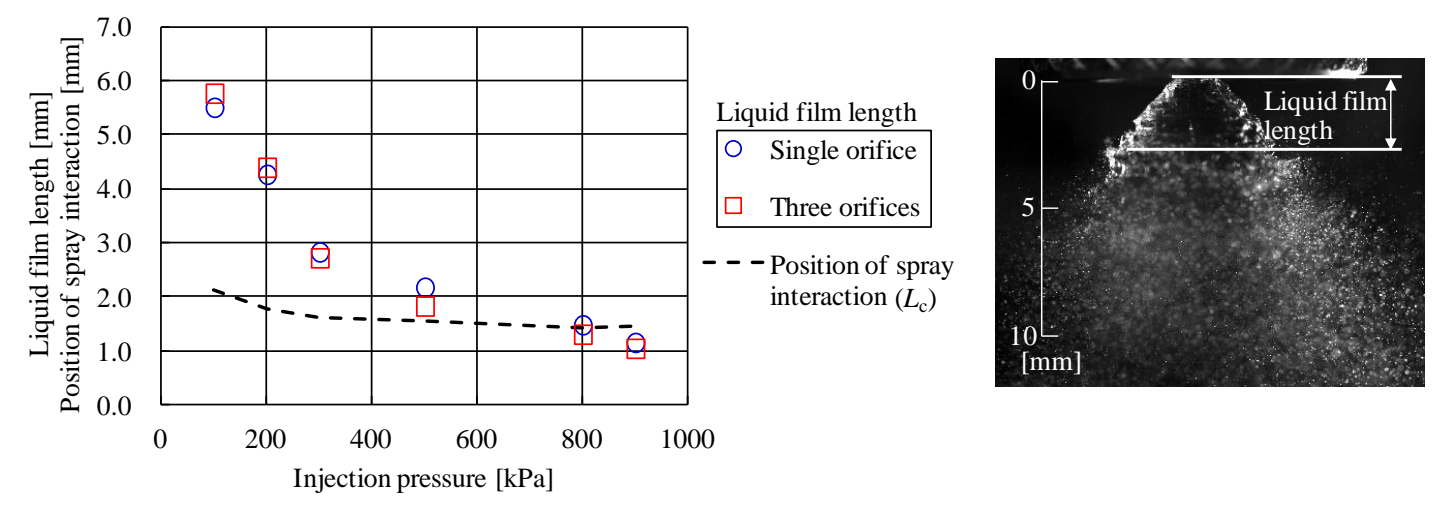

Fig. 8 Liquid film length as a function of injection pressure. The position of spray interaction $L_{\mathrm{c}}$ calculated by eq. (2) is also displayed. This figure shows that the liquid films collided with each other when the injection pressure was lower than $500 \mathrm{kPa}$.

以上より，噴霧干渉の粒径への影響は以下のように考えられる. 噴射差圧が小さい場合，図 9 (a)のように噴霧 は液膜の状態で干渉しており，液膜の一部が合体して厚くなるため，分裂時の粒径が大きくなる，噴射差圧が十 分大きい場合，図 9 (b)のように噴霧は液滴の状態で干渉しており，液滴は衝突してもほとんど合体せず，粒径に 影響は見られなかった.

ただし，液滴同士の衝突に関して，噴霧の流量が少ない条件下では液滴が衝突後に合体して粒径が大きくなる ことが文献(Hardalupas and Whitelaw, 1996)により示されている. よって, 本研究の実験条件における液滴合体の可 能性を検討する必要がある.液滴の Weber数と impact parameterを用いて液滴の衝突挙動を整理している文献(Qian and Law, 1997)により, (1)Weber 数が低い場合, または(2)Weber 数と impact parameter の関係によって定義される特 定の領域内において，液滴同士が結合したままになる合体(Coalescence)が生じるという結果が示されている．よ って(1)と(2)それぞれについて考察する.

(1) Weber 数が低い場合

噴孔出口の液膜厚さと速度から算出した Weber 数は, 液滴衝突の生じる $500 \mathrm{kPa} \sim 900 \mathrm{kPa}$ では $390 \sim 730$ 程度 であった. Qian らの結果は Weber 数が 100 以下のため, Weber 数が 750 程度での Weber 数と impact parameter の 関係を推測すると，ほぼ跳ね返り (Bouncing)または合体後に分裂(Separation)であると考えられる. Weber 数は慣性 
力/表面張力の無次元数であり, 数值が大きいほど慣性が強く, 結合状態を維持しにくいことを意味していること からも妥当であると言える.

(2) Weber 数と impact parameterの関係によって定義される特定の領域

Impact parameter は液滴間距離液滴径で定義されることから, 噴霧中で衝突する液滴は全ての值をとり得る. しかしながら, Qian らのグラフの傾向から, Weber 数が大きくなるにつれ合体(Coalescence)する impact parameter の範囲は非常に狭くなると予想される.

以上から, 本研究では液滴の跳ね返り (Bouncing)や合体後の分裂(Separation)が生じや寸い実験条件となっており, 液滴同士が衝突しても液滴径は大きくなりにくく，粒径への影響は小さかったと考えられる.

(a)

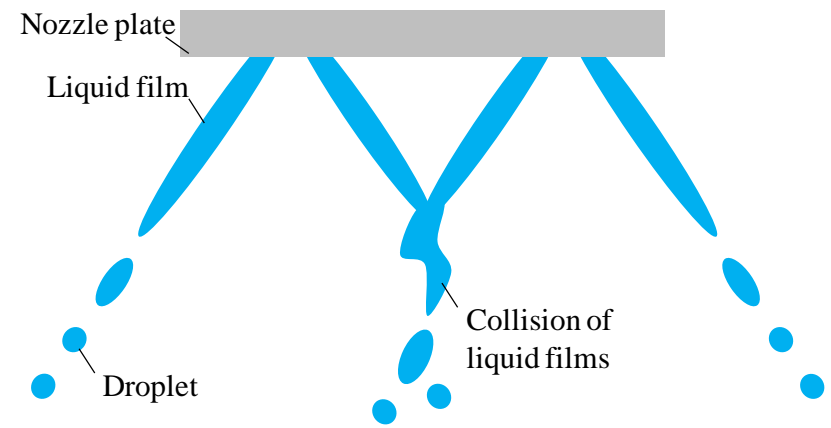

(b)

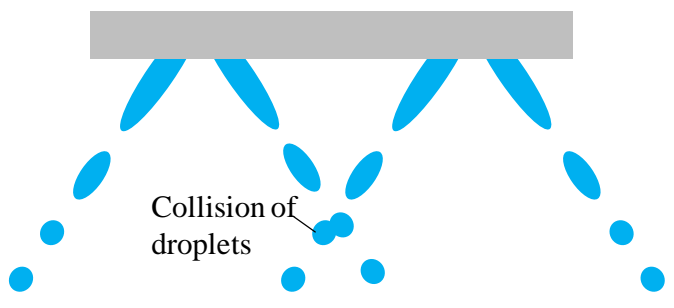

Fig. 9 Schematics of spray interaction. (a) Liquid film collision. (b) Droplet collision. The liquid film merges if the liquid films collide with each other. It is hard for droplets to merge even if droplet collision occurred in our experimental conditions.

次に，噴霧干渉が噴霧角へ与える影響について検討する，中空円錐状の噴霧では，噴霧の広がり（噴霧角）が 大きいほじ噴孔出口より下流で液膜が薄くなるため, 液膜分裂後の粒径が小さくなる傾向がある. 図 10 に噴霧角 の測定結果を示す，噴霧角は噴射直後の噴霧の広がり角度として定義し，撮影した噴霧画像から測定している. 横軸は噴射差圧，縦軸は噴霧角である．噴霧角は噴射差圧の増加と共に大きくなっていることが分かる．また， 単孔ノズルと 3 孔ノズルの噴霧角の差異はほとんど見られない，噴霧干渉はノズルプレートの中心側で生じてお り，噴霧角は干渉の無い噴霧の外縁形状から決まっている．よって噴霧干渉が噴射直後の噴霧角へ与える影響は 小さく，また各孔の噴霧角もほとんど変わっていないことが分かる．図６で示したように，噴孔 $15 \mathrm{~mm}$ 下では単 孔ノズルと 3 孔ノズルで噴霧の広がりに差が見られたことから，噴射直後は噴霧の慣性力が強く，噴霧による圧 力低下の影響を受けにくいが，噴霧下流では圧力低下の影響が噴霧形状に表れていると考えられる.
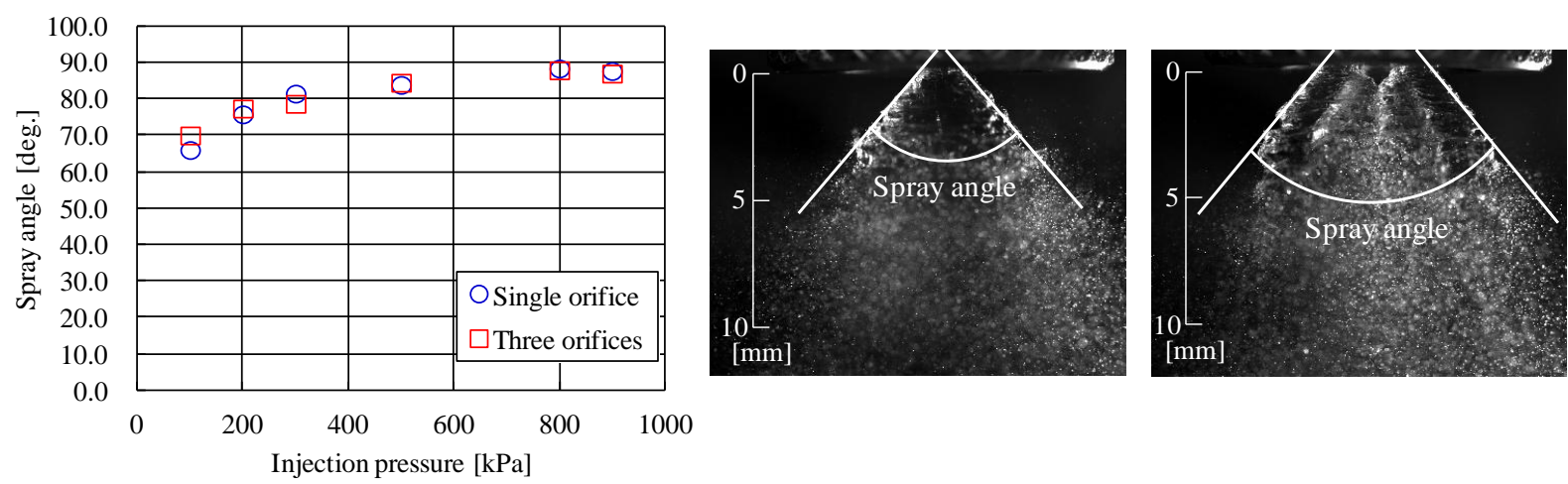

Fig. 10 Measured spray angles as a function of injection pressure. The influences of spray interaction are not seen because the spray angle is defined at the edge of the assembled spray shape where the sprays do not interact. 


\section{3. ノズル内部の流れ場の検討}

上述した結果より，多孔スワールインジェクタでは，噴霧同士の液膜干渉が生じた場合，微粒化性能に影響す ることが分かった．微粒化性能に影響寸る他の要因としては，旋回流によって噴孔内で形成される液膜厚さがあ る(Rizk and Lefebvre, 1980). しかしながら, 実験で噴孔出口の液膜厚さを測定することは難しい. そこで本研究 では，気液二相流の数值解析を実施し，多孔化が噴孔出口の液膜厚さに与える影響について検討した.

\section{$3 \cdot 1$ 数值解析手法}

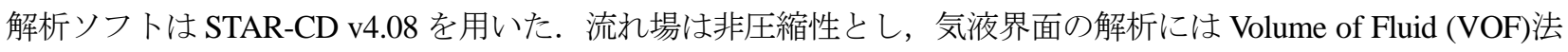
を用いた．流れの支配方程式は次式で示寸質量及び運動量の保存式で表される.

$$
\begin{aligned}
& \nabla \cdot \boldsymbol{v}=0 \\
& \rho \frac{\partial \boldsymbol{v}}{\partial t}+\rho \nabla \cdot(\boldsymbol{v} \boldsymbol{v})=-\nabla P+\mu \nabla^{2} \boldsymbol{v}+\rho \boldsymbol{g}+\boldsymbol{F}
\end{aligned}
$$

ここで, $v$ は速度ベクトル,$t$ は時間, $\rho$ は密度, $P$ は圧力, $\mu$ は粘度, $g$ は重力加速度, $\boldsymbol{F}$ は体積力である. 密度 $\rho$ 及び粘度 $\mu$ は液相体積分率 $f$ を用いて次式で表される。

$$
\begin{aligned}
& \rho=(1-f) \rho_{\mathrm{g}}+f \rho_{1} \\
& \mu=(1-f) \mu_{\mathrm{g}}+f \mu_{1}
\end{aligned}
$$

添え字 $\mathrm{g}$ と 1 はそれぞれ気相と液相を意味している. 液相体積分率 $f$ は次式で表される.

$$
f=\frac{V_{1}}{V_{1}+V_{\mathrm{g}}}
$$

ここで $V_{1}$ と $V_{\mathrm{g}}$ はそれぞれ液相と気相の体積である. $f$ は各セルでの瞬時值であり,$f=1$ は液相,$f=0$ は気相を意 味している. fの輸送方程式は次式で表される.

$$
\frac{\partial f}{\partial t}+(v \cdot \nabla) f=0
$$

表面張力による力の計算には，次式で表される Continuum Surface Force モデル(Brackbill et al., 1992)を用いた.

$$
\boldsymbol{F}=\sigma \kappa \nabla f
$$

ここで,

$$
\kappa=-\nabla \cdot\left(\frac{\nabla f}{|\nabla f|}\right)
$$

である， $\sigma$ は表面張力である.

図 11 に解析モデルを示寸. (a)は単孔ノズルのモデル，(b)は 3 孔ノズルのモデルであり，実験に用いたものと 同一形状とした．流入境界，流出境界は圧力固定とした．壁面は寸べり無し条件とした．セル数はそれぞれ約 47 万，139 万である．表 2 に解析に用いた物性值を示寸， $\theta_{\text {contact }}$ は接触角である.

Table 2 Physical properties.

\begin{tabular}{|c|c|c|c|c|}
\hline & $\rho\left[\mathrm{kg} / \mathrm{m}^{3}\right]$ & $\mu[\mathrm{Pa} \cdot \mathrm{s}]$ & $\sigma[\mathrm{N} / \mathrm{m}]$ & $\theta_{\text {contact }}[\mathrm{rad}]$ \\
\hline Gasoline & 752 & $7.69 \times 10^{-4}$ & 0.0180 & $\pi / 2$ \\
\hline Air & 1.21 & $1.83 \times 10^{-5}$ & - & - \\
\hline
\end{tabular}


(a)

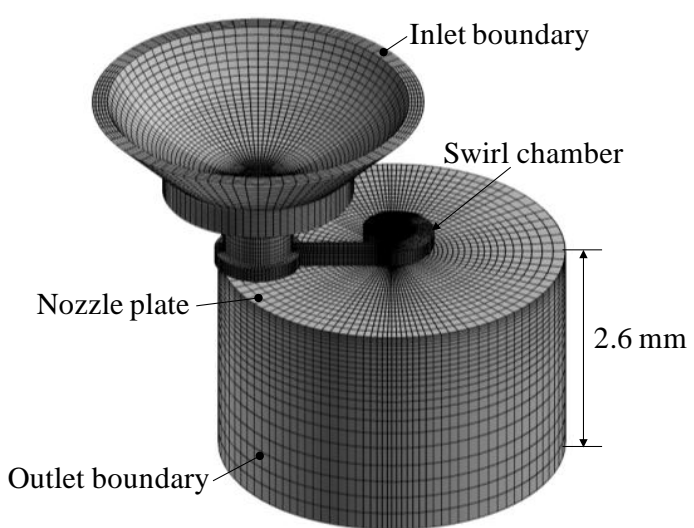

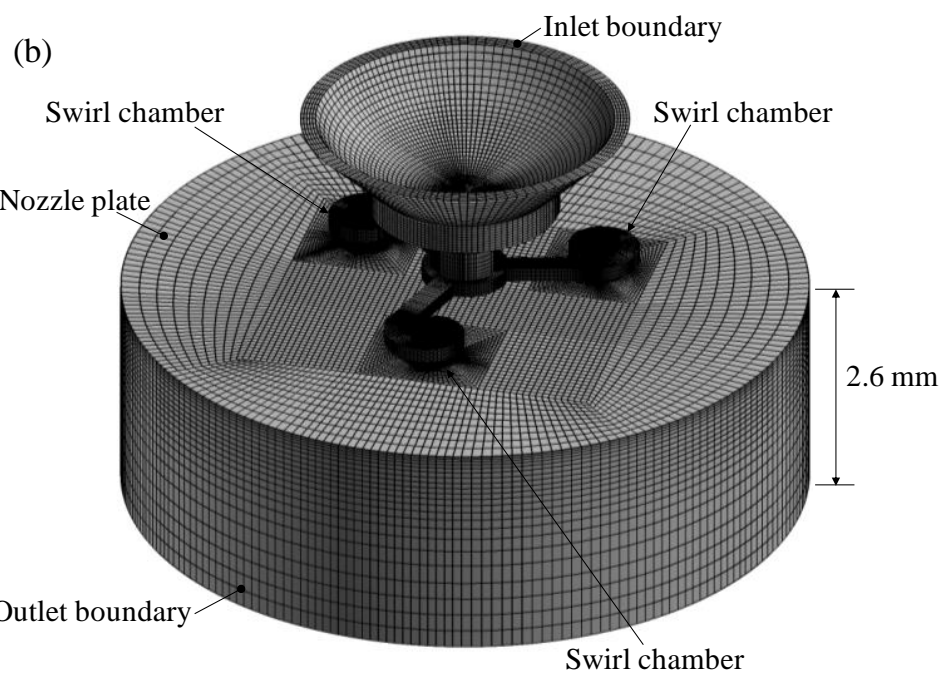

Fig. 11 Analysis models with (a) the single orifice and (b) the three orifices. The total number of cells is (a) 0.47 million and (b) 1.39 million.

(a)

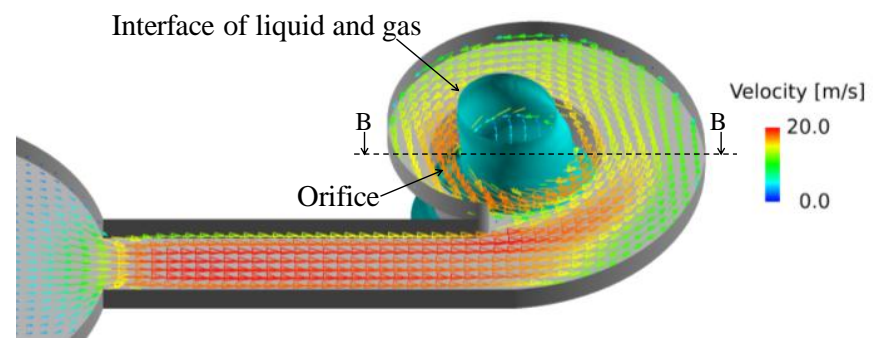

(c) (b)

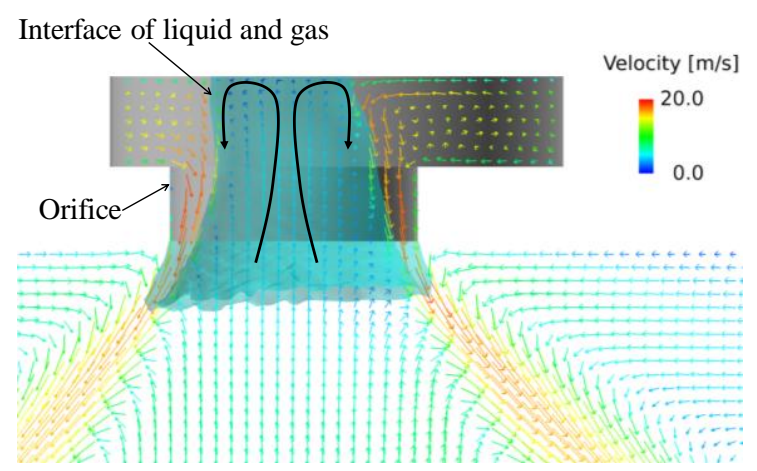

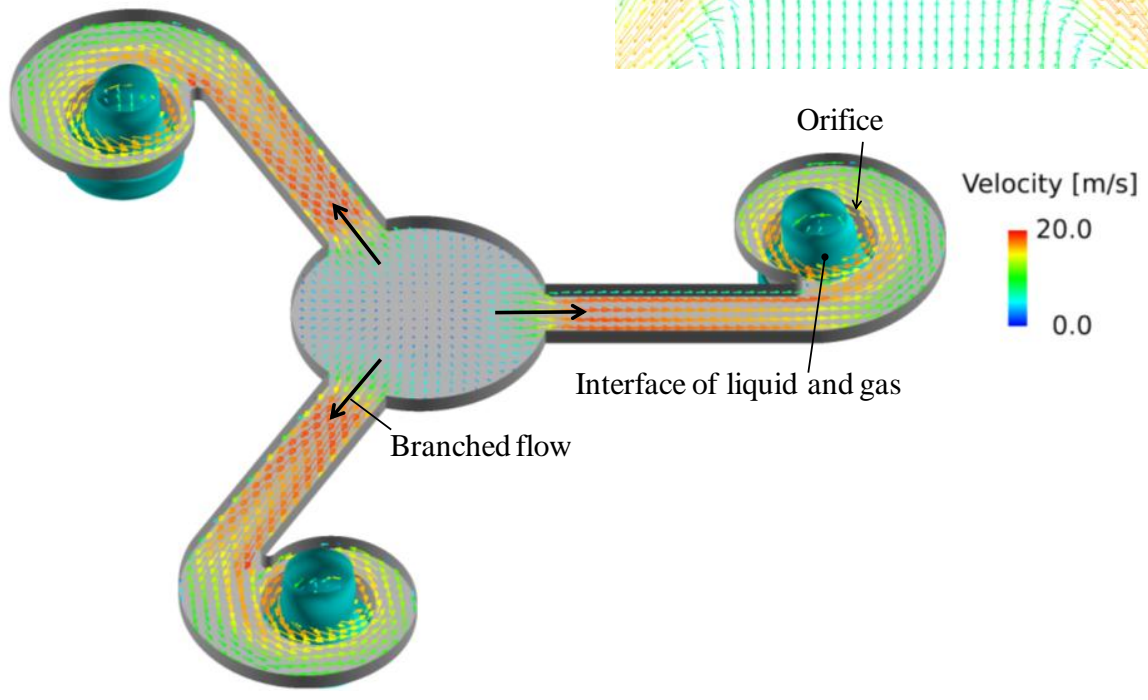

Fig. 12 Visualization of velocity vectors and gas-liquid interface near the orifice with (a) the single orifice, (b) section B-B, and (c) the three orifices. Air penetrates into the swirl chamber because the centrifugal force produced by swirling flow decreases the pressure in the center of the swirl chamber and the orifice.

\section{$3 \cdot 2$ 解析結果}

ノズル内の流れ場を困 12 に示す. (a)は単孔ノズルの流れ場，(b)は(a)の噴孔中心における B-B 断面，(c)は 3 孔 ノズルの流れ場である。ベクトルは速度, 気液界面は液相の体積分率 $f$ が 0.5 となる等值面を表示している。噴 射差圧は $300 \mathrm{kPa}$ とした．図より，単孔，3 孔の結果は共に，旋回室内で壁面に沿った旋回流が生じており，旋回 室内には噴孔から空気が入り込んでいることが分かる．これは旋回室内の旋回流によって遠心力が発生し，旋回 
の中心側が低圧となるためである．また，ノズル内部では旋回室上流の直線流路で最も流速が大きくなっている が，これは直線流路の断面積が，単孔ノズルと 3 孔ノズル共に全流路中で最小となっているためである.

(a)

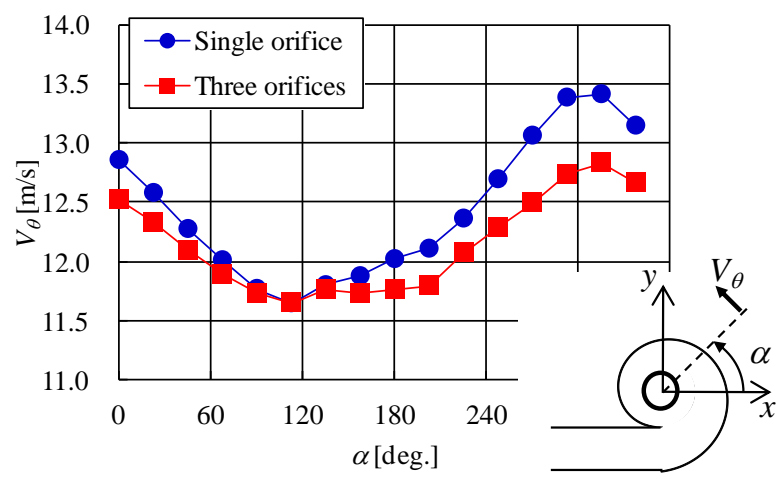

(b)

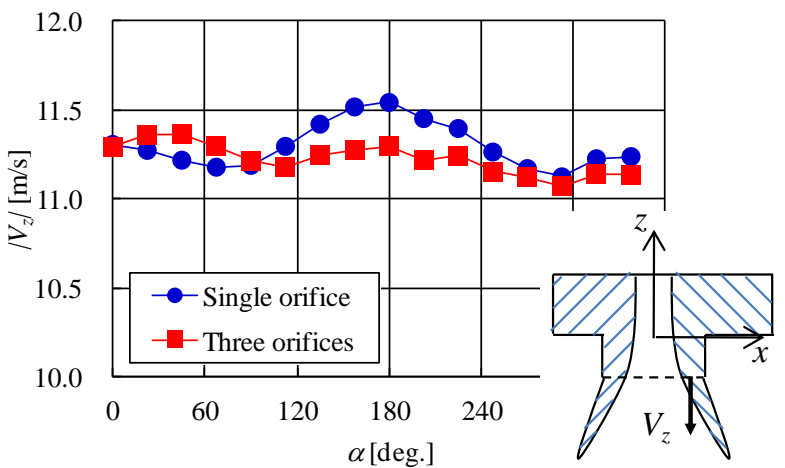

Fig. 13 (a) Circumferential velocity $V_{\theta}$ and (b) axial velocity $V_{z}$ profiles for the single orifice and the three orifices at orifice outlet in circumferential direction. $V_{\theta}$ and $V_{z}$ of the three orifices are smaller than those of the single orifice in most regions of the circumferential angle $\alpha$.

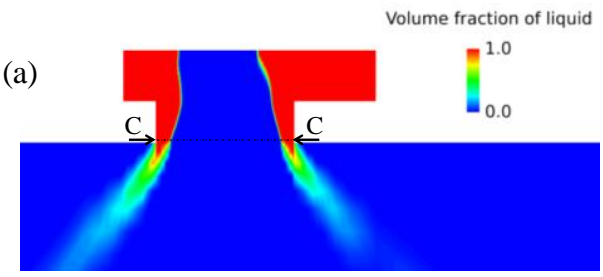

(b)

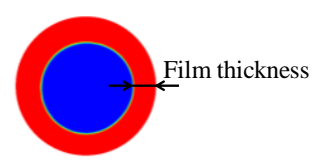

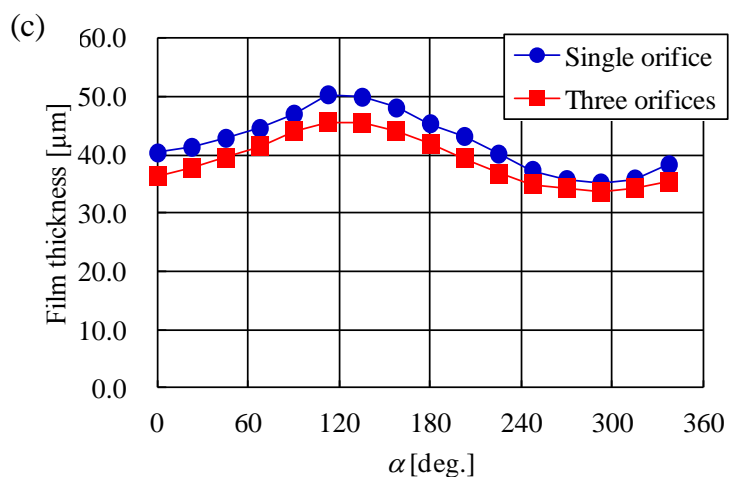

Fig. 14 Fuel distribution calculated in the orifice. (a) Fuel distribution at cross section of the orifice center. (b) Section C-C. (c) Film thickness versus circumferential angle $\alpha$ at the orifice outlet. The film thickness of the three orifices is thinner than that of the single orifice.

図 13 に噴孔出口の液相の周方向速度 $V_{\theta}$ と, 噴孔の軸方向速度 $V_{z}$ の絶対值の分布を示す.グラフの縦軸は, 噴 孔出口を周方向に等分割し，分割した各領域の液相の速度を平均化したものである．横軸は噴孔の周方向角度 $\alpha$ である. 図 13 より， $V_{\theta}$ 分布のピーク位置は単孔ノズルと 3 孔ノズルでほぼ一致しているが，速度の大きさは $V_{\theta},\left|V_{z}\right|$ 共に 3 孔ノズルの方が小さくなる傾向がある.この原因を検討するため, 表 3 に流入境界で測定した流量 を示す. 3 孔ノズルでは流量が単孔ノズルの 3 倍程度となっている. これによって弁体とノズル体によって流路 絞りとなるシート部（図 1 の Seat area 参照）でも流速が 3 倍程度となり，3 孔ノズルでは単孔ノズルを備えたイ ンジェクタのシート部よりも圧力損失が大きくなる。このため 3 孔ノズルでは各孔あたりの流量が小さくなり， 結果として噴孔出口の流速も小さくなったと考えられる. 一方で，3 孔ノズルの各孔あたりの流量が単孔ノズル よりも小さくなると，シート部とは逆に，単孔ノズルの方が直線流路や噴孔の絞りによる圧力損失は大きくなる はずである。しかしながら，直線流路及び噴孔では単孔ノズルと 3 孔ノズルの流速差はシート部に比べて小さい ため，シート部ほどの圧力損失の差は生じない. 流速に大きな差がないことは, 図 12 (a)と(c)の比較からも確認 できる. 結果として，3 孔ノズルの方が各孔あたりの流量が小さくなるため， $V_{\theta},\left|V_{z}\right|$ は小さくなっている.

図 14 に噴孔内における液膜分布を示寸. (a)は旋回室と噴孔中心断面の燃料分布，(b)は噴孔出口の断面図であ る. 図より，噴孔出口となる C-C 断面では然料の液膜がリング状に形成されている様子が分かる.図 14 (c) は, C-C 断面における周方向角度 $\alpha$ に対する液膜厚さの分布である. 液膜厚さは図12の速度と同様に平均化したもの をプロットしている. 図13 (a)と比較すると, $V_{\theta}$ が最大となる $\alpha$ にいて液膜厚さはほぼ最小となり, $V_{\theta} か ゙$ 最小と 


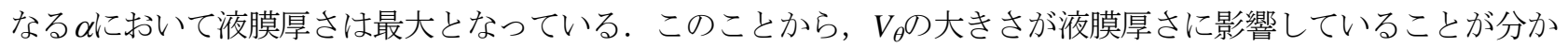
る. また, 3 孔ノズルでは単孔ノズルより液膜厚さが薄くなっている.この原因を検討するため, 表 3 に流量と 噴孔出口全体における液膜厚さ及び $\left|V_{z}\right|$ 平均值を, 単孔ノズルと 3 孔ノズルで比較したものを示す. 表より, 多 孔化による $V_{z}$ の変化量は-0.9\%だが，単孔あたりに変換した場合の流量変化量は-6.8 \%, 液膜厚さの変化は-6.4\% である.つまり流量の変化によって, 液膜が薄くなったことが分かる. 図 7 (b)の高圧側において 3 孔ノズルで SMD が小さくなったのは，このことが要因であったと考えられる. なお，図 15 より噴射差圧によらず，単孔ノズルよ り 3 孔ノズルの液膜厚さが薄くなる傾向があることが確認できる.

Table 3 Calculated value of flow rate, averaged film thickness, and $\left|V_{z}\right|$.

\begin{tabular}{|c|c|c|c|}
\hline & $\begin{array}{c}\text { Calculated flow rate } \\
{\left[\mathrm{cm}^{3} / \mathrm{min}\right]}\end{array}$ & $\begin{array}{c}\text { Film thickness } \\
{[\mu \mathrm{m}]}\end{array}$ & $\begin{array}{c}\left|V_{z}\right| \\
{[\mathrm{m} / \mathrm{s}]}\end{array}$ \\
\hline Single orifice & 33.9 & 42.2 & 11.3 \\
\hline Three orifices & $\begin{array}{c}94.8 \\
(31.6 \text { per orifice })\end{array}$ & 39.5 & 11.2 \\
\hline Difference & $-6.8 \%$ & $-6.4 \%$ & $-0.9 \%$ \\
\hline
\end{tabular}

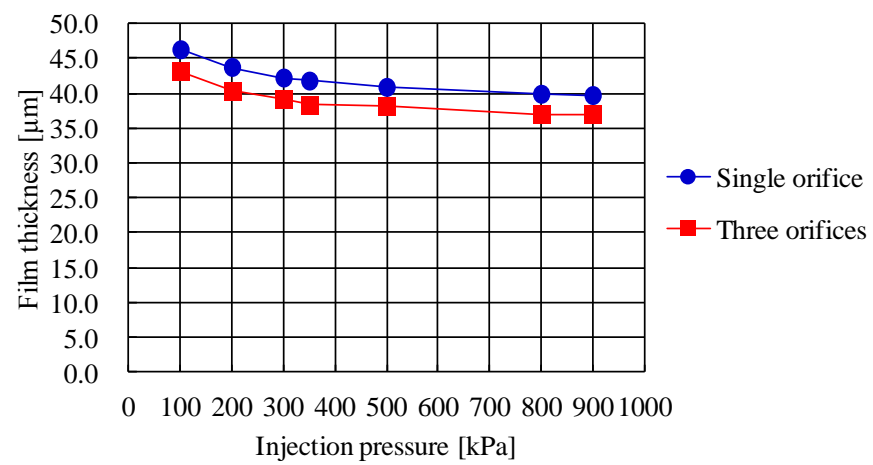

Fig. 15 Averaged film thickness at the orifice outlet in circumferential direction versus injection pressure. The results of the three orifices are smaller than that of the single orifice for all injection pressure conditions.

\section{4. 平均粒径の算出手法の検討}

\section{$4 \cdot 1$ 算出手法}

上記実験と解析で得られた知見を基に，スワールインジェクタによる噴霧の平均粒径を，簡易に算出する手法 を開発した. 具体的には, Miyamoto ら(Miyamoto et al., 1996)により提案されている環状液膜流の分裂のモデル化 による平均粒径の算出式を修正し，スワールインジェクタの噴霧に適用した．平均粒径の算出に必要な值は上述 したノズル内部の数值解析により求めた.

本研究での粒径算出方法について説明する. 宮本らは噴孔出口で液膜が分裂するとし, 噴射する液膜の厚さ $h$ と，気液の相対速度 $W$ を用いて次式により平均粒径(SMD)を算出している.

$$
\mathrm{SMD}=A\left(\frac{\sigma}{\rho_{g} W^{2}}\right)^{\frac{2}{3}} h^{\frac{1}{3}}
$$

式(11)は Weber 数の形を用いて整理され，次式のように表すことができる.

$$
\mathrm{SMD}=A(W e)^{-\frac{2}{3}} h
$$




$$
W e=\frac{\rho_{g} W^{2} h}{\sigma}
$$

一方，本研究で対象としているスワールインジェクタでは，空気の速度は燃料の噴射速度よりも十分遅いことか ら，相対速度 $W$ ではなく，燃料の噴孔軸方向速度 $V_{z}$ を用いた．また，噴孔から噴射後に液膜が円錐状に広がる ため，下流になるほど液膜が薄くなる．このため，より精度よく粒径を予測するためには，噴孔出口からどの程 度下流で液膜が分裂するかを考慮する必要がある．そこで本研究では式(12)の液膜厚さ $h$ を，液膜が分裂する時 点での液膜厚さ $h$ ’とした.

$$
\begin{aligned}
& \mathrm{SMD}=A(W e)^{-\frac{2}{3}} h^{\prime} \\
& W e=\frac{\rho_{g} V_{z}{ }^{2} h}{\sigma}
\end{aligned}
$$

式(14)，(15)の未知の值は $V_{z}$ と $h, h$ である. $A$ は定数であり，任意に設定される $A$ の值によって算出される SMD の值が変化する．噴射差圧が高い場合は液滴衝突であることを考慮し，900 kPa におおる実験と解析の SMD がほ ぼ一致するように $A$ の值を設定した．設定値は 4.2 節で後述する. 式(15)の速度 $V_{z}$ と液膜厚さ $h$ は噴孔出口の值 を与えた. 次に, $h$ ’算出方法について説明する. 図 16 に示寸ように, 噴孔出口面と, 噴孔出口面から $L \cos \theta$ 下 に位置する平面において, 流量が保存されかつ流速が等しいと仮定すると，リング状に形成される液膜の断面積 について，次式が成立する.

$$
\pi(r+h)^{2}-\pi r^{2}=\pi\left(r^{\prime}+h^{\prime}\right)^{2}-\pi r^{\prime 2}
$$

ここで，r, r'は次式で定義され，図 16 に示寸ように噴孔の半径と, 液膜長さ $L$ の位置における噴霧の位置の半 径を意味する.

$$
\begin{aligned}
& r=\frac{d_{o}}{2}-h \\
& r^{\prime}=\frac{V_{\theta}}{V_{z}} L \cos \theta+r \\
& \cos \theta=\frac{1}{\sqrt{1+\left(V_{\theta} / V_{z}\right)^{2}}}
\end{aligned}
$$

式(17), (18), (19)を式(16)に代入すると, 液膜長さ $L$ の位置における液膜厚さ $h$ ’は次式で表される.

$$
h^{\prime}=-\left(\frac{d_{o}}{2}-h+\frac{V_{\theta}}{V_{z}} L \cos \theta\right)+\left[\left(\frac{d_{o}}{2}-h+\frac{V_{\theta}}{V_{z}} L \cos \theta\right)^{2}+h\left(d_{o}-h\right)\right]^{0.5}
$$

液滴への分裂長さ $L_{\mathrm{BU}}$ は，Han ら(Han et al., 1997)による円錐状液膜の分裂の式を用いて求める.

$$
L_{\mathrm{BU}}=B\left[\frac{\rho_{l} \sigma \ln \left(\eta / \eta_{0}\right) h^{\prime} \cos ^{2} \theta}{\rho_{g}{ }^{2} V_{z}^{2}}\right]^{0.5}
$$

式(21)は Han らの式の液膜厚さの変数に対して $h^{\prime} \cos \theta$ を代入した形になっている. $\eta$ は液膜分裂時の波の振幅, $\eta_{0}$ は初期擾乱の振幅であり, $\ln \left(\eta / \eta_{0}\right)$ は Reynolds 数によって異なる (Clark and Dombrowski, 1972). B は定数であ る. 本研究では噴射差圧によらず, Han らが使用している值である $\ln \left(\eta / \eta_{0}\right)=12, B=3$ を用いた. 液膜長さ $L$ と分 
裂長さ $L_{\mathrm{BU}}$ が等しいと仮定し, 式(20)，(21)を解く事で，液膜分裂時の液膜厚さ $h$ ’を求めることが出来る. $h, V_{z}, V_{\theta}$ は数值解析の結果から, 噴孔出口における平均值を与えた.

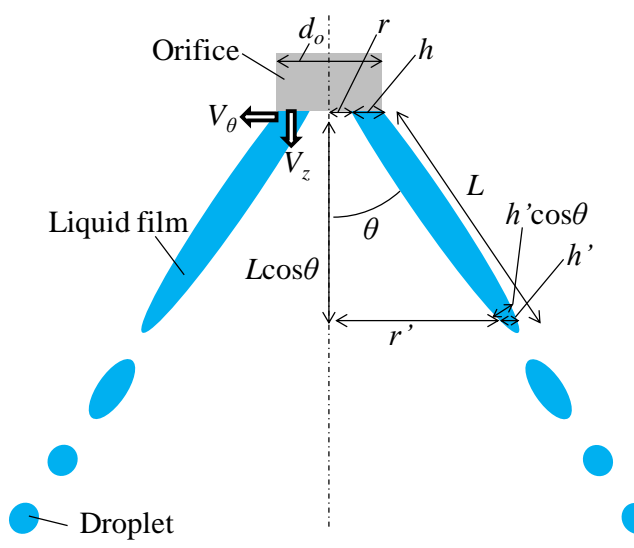

Fig. 16 Schematic of hollow-cone spray and variables used in calculating value of SMD.

\section{$4 \cdot 2$ 結果の検討}

次に，上述した粒径算出手法を検証した結果について述べる. 本研究では液膜の分裂距離と平均粒径を算出す る際に，3章で解析した単孔ノズル及び 3 孔ノズルのモデルを用いた.

図 17 は単孔ノズルの液膜長さの実験值と，式(19)，(21)を用いて算出した值 $L \cos \theta$ 比較したグラフである.こ こでは計算上，液膜分裂長さ $L_{\mathrm{BU}}$ と液膜長さ $L$ は等しいと仮定している．グラフの横軸は噴射差圧，縦軸は噴孔 出口からの距離である，グラフより，低圧側で実験との差が大きく，算出值は実験值よりも液膜長さが短くなっ ている．一方，高圧側ではよく一致している．噴射差圧によって Reynolds 数が変化する場合は $\ln \left(\eta / \eta_{0}\right)$ の最適值 が異なるが，本研究では一定值としたために，高圧側ではよく一致し，低圧側では誤差が生じたと考えられる.

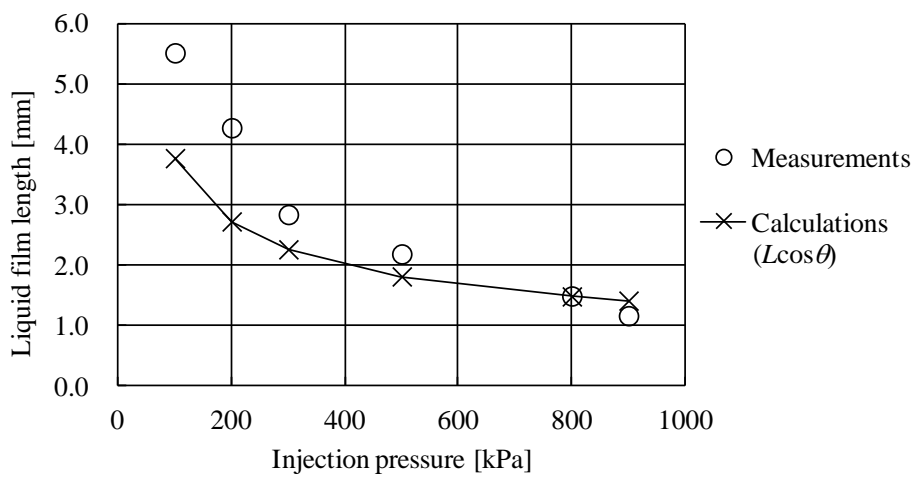

Fig. 17 Comparison of measured and calculated liquid film length. The calculated results agree well with the measured ones at a high injection pressure condition, while they do not agree at a low injection pressure condition. This is because a constant $\ln \left(\eta / \eta_{0}\right)$ is used in this study.

図 18 (a)に単孔ノズル，(b)に3 孔ノズルの平均粒径(SMD)の実験值と，式(14)を用いて算出した粒径の算出値を 示す. また, $h^{\prime}$ にる平均粒径の算出式の修正の効果を確認するために, 液膜の分裂距離を考慮していない式(12) を用いて計算した值も示す．ただし，Weの計算には共に式(15)を用いた. 式(12), (14)で用いる定数 A は, 噴霧

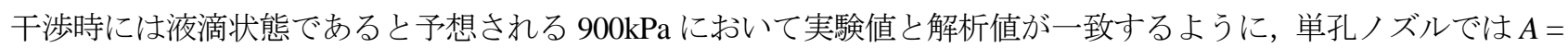
0.57 と $A=4.8,3$ 孔ノズルでは $A=0.51$ と $A=4.4$ とした. 図 18 (a)より単孔ノズルの実験值と算出值を比較する と，式(14)による算出值は式(12)と比べて，実験值とよく一致している．液膜の分裂長さを考慮していない式(12) では分裂時の液膜厚さ $h$ が実際よりも大きい值となるために, 粒径が実験值より大きくなっていると考えられる. 
式(14)では分裂時の液膜厚さをより適切に評価することで, 実験值の傾向に近づいたと言える. 以上より液膜長 さを考慮することで，単孔ノズルのスワールインジェクタの粒径は精度よく予測可能であることが分かった．ま た，図 18 (b)からは，3 孔ノズルの実験值と式(14)による算出值は高圧側ではよく一致していることが分かる．一 方，低圧になると算出値は実験值よりも小さくなる傾向がある。これは実験では液膜衝突により液膜が合体して 厚くなっているが，解析による粒径算出ではそれを考慮していないことが原因であると言える．以上より，本研 究の粒径算出手法は液滴衝突が生じる範囲で多孔スワールインジェクタの平均粒径を予測可能であることが分か った.

(a)

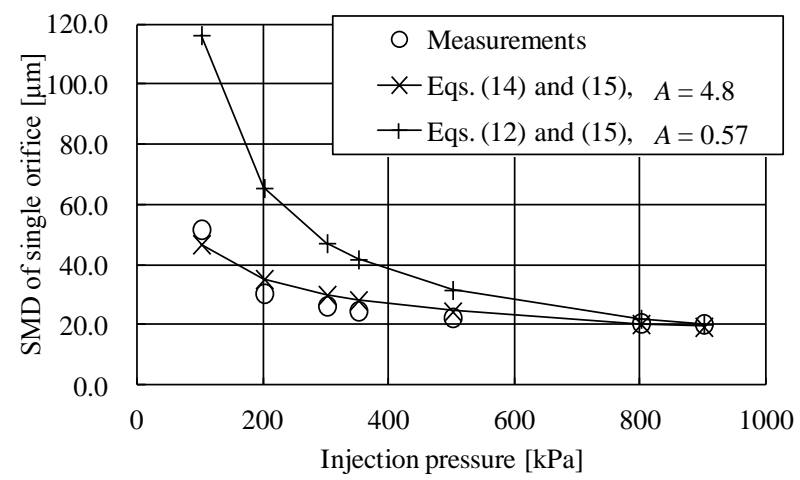

(b)

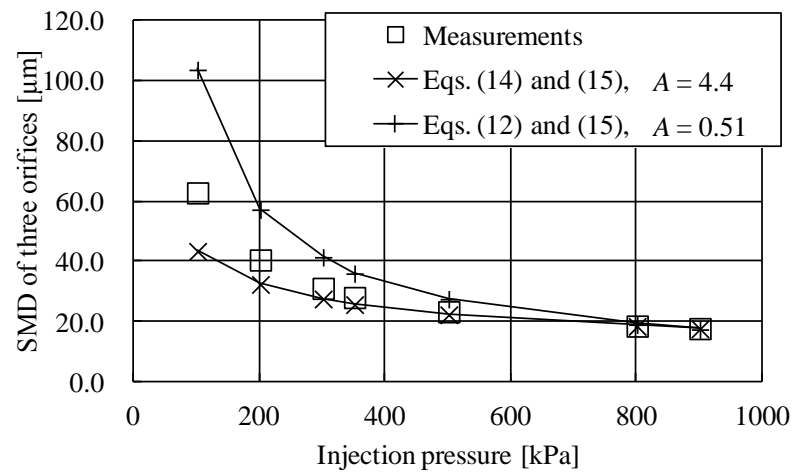

Fig. 18 Comparison of measured SMD and calculated mean droplet diameter with eqs. (12) or (14) in (a) a single orifice and (b) three orifices. The present results are in good agreement with the measured SMD of the single orifice. However, the present results of the three orifices have a gap from measurements at a low injection pressure condition because liquid film collision is not modeled in our study.

\section{5. 結 言}

本研究では多孔スワールインジェクタによる噴霧の微粒化現象に関して，噴霧の可視化，平均粒径の測定及び 数值解析を用いて検討した．さらにこれらの知見を基に，噴霧の平均粒径を簡易に算出する手法を開発した．本 研究で得られた主な結果は以下の通りである.

1. スワールインジェクタを多孔化すると，噴霧同士の干渉が生じる．燃料が液膜の状態で干渉した場合は SMD が悪化する，一方で燃料が液滴の状態で干渉した場合は，本研究の実験条件では SMD の変化は小さ い．これは，噴霧中の液膜が衝突した場合は合体して大きな液滴が生成されるが，液滴の状態で噴霧が干 渉した場合は，液滴が衝突しても液滴同士が結合したままになりにくく，粒径への影響が小さかったため である.

2. インジェクタ先端のノズル内部の気液二相流の数值解析を実施し，ノズル内部流れの観点から，多孔化が 粒径に与える影響について検討した．解析結果から，局所的な旋回速度が膜厚形成に影響していること， また，多孔化すると噴射差圧によらず液膜厚さが薄くなっていることが明らかとなった．これは多孔化に よって各孔あたりの流量が低下したことが原因である．噴霧が液滴で干渉している場合は，この影響によ り，単孔よりも多孔スワールインジェクタの SMD が小さくなることが分かった.

3. 中空円錐状の噴霧における液膜の分裂長さを考慮した粒径算出手法を構築した. 算出結果と実験結果を比 較すると, 多孔の低圧側では解析結果と実験結果の差異が大きいが，単孔の場合，及び多孔の高圧側にお いては粒径の算出値はSMD の測定結果とよく一致した。これは液膜の合体の影響を粒径算出手法では考 慮していないためである．よって本研究の粒径算出手法は液膜干涉をしていない場合は SMD を予測可能 であることが分かった。 


\section{文献}

Befrui, B. and D'Onofrio, M., Primary atomization of a GDi multi-hole plume using VOF-LES method, SAE Technical Paper (2014), 2014-01-1125.

Brackbill, J. U., Kothe, D.B. and Zemach, C., A continuum method for modeling surface tension, Journal of Computational Physics, Vol. 100 (1992), pp. 335-354.

Clark, C. J. and Dombrowski, N., Aerodynamic instability and disintegration of inviscid liquid sheets, Proceedings of the Royal Society of London A, Vol. 329 (1972), pp. 467-478.

Han, Z., Parrish, S., Farrell, V. P. and Reitz, D. R., Modeling atomization processes of pressure-swirl hollow-cone fuel sprays, Atomization and Sprays, Vol. 7 (1997), pp. 663-684.

Hardalupas, Y. and Whitelaw, J. H., Interaction between sprays from multiple coaxial airblast atomizers, Journal of Fluids Engineering, Vol. 118 (1996), pp. 762-771.

Hirt, C. W. and Nichols, B. D., Volume of fluid method for the dynamics of free boundaries, Journal of Computational Physics, Vol. 39 (1981), pp. 201-225.

Inamura, T., Tamura, H. and Sakamoto, H., Characteristics of liquid film and spray injected from swirl coaxial injector, Journal of Propulsion and Power, Vol. 19, No. 4 (2003), pp. 632-639.

Ishii, E., Ishikawa, M., Sukegawa, Y. and Yamada, H., Secondary-drop-breakup simulation integrated with fuel-breakup simulation near injector outlet, Journal of Fluids Engineering., Vol. 133 (2011).

小林清志，渦巻き噴射弁の微粒化特性（第 4 報 液体の性質が噴霧角および粒径に及ぼす影響），日本機械学会論 文集，Vol. 19, No. 80 (1953), pp. 64-68.

Miyamoto, T., Kobayashi, T. and Matsumoto, Y., Structure of sprays from an air-assist hollow-cone injector, SAE Technical Paper (1996), 960771.

Qian, J. and Law, C. K., Regimes of coalescence and separation in droplet collision, Journal of Fluid Mechanics, Vol. 331 (1997), pp. 59-80.

Rizk, N. K. and Lefebvre, A.H., Influence of liquid film thickness on airblast atomization, Journal of Engineering for Power, Vol. 102, No.3 (1980), pp. 706-710.

Rizk, N. K. and Lefebvre, A.H., Internal flow characteristics of simplex swirl atomizers, Journal of Propulsion and Power, Vol. 1, No. 3 (1985), pp. 193-199.

Samenfink, W., Albrodt, H., Frank, M., Gesk, M. and Melsheimer, A., Strategies to reduce HC-emissions during the cold starting of a port fuel injected gasoline engine, SAE Technical Paper (2003), 2003-01-0627.

Tani, Y., Mori, Y. and Mochizuki, K., Multiple-hole nozzle atomization for SI engines, SAE Paper(1999), 1999-01-0564.

谷泰臣, 岡本敦哉, 稲垣英人，鈴木孝司，多孔型プレートノズルにおける中空円錐噴霧の形成，第 11 回微粒化シ ンポジウム(2002), pp. 94-97.

Tani, Y., Iwamoto, M., Suzuki, T. and Inoue, Y., Multiple hollow-cone-like spray formation by controlling internal flow of multiple hole nozzles, Proceedings of ICLASS-2006 (2006), ICLASS06-068.

Yasukawa, Y. and Okamoto, Y., Fine atomization and low penetration fuel spray by using a multi-swirl nozzle for automobile engines, Proceedings of FEDSM2007 (2007), FEDSM2007-37013.

Yasukawa, Y., Okamoto, Y., Kobayashi, N., Saito, T. and Saruwatari, M., Multi-swirl type injector for port fuel injection gasoline engines, SAE Technical Paper (2014), 2014-01-1436.

\section{References}

Befrui, B. and D'Onofrio, M., Primary atomization of a GDi multi-hole plume using VOF-LES method, SAE Technical Paper (2014), 2014-01-1125.

Brackbill, J. U., Kothe, D.B. and Zemach, C., A continuum method for modeling surface tension, Journal of Computational Physics, Vol. 100 (1992), pp. 335-354.

Clark, C. J. and Dombrowski, N., Aerodynamic instability and disintegration of inviscid liquid sheets, Proceedings of the Royal Society of London A, Vol. 329 (1972), pp. 467-478.

Han, Z., Parrish, S., Farrell, V. P. and Reitz, D. R., Modeling atomization processes of pressure-swirl hollow-cone fuel sprays, Atomization and Sprays, Vol. 7 (1997), pp. 663-684.

Hardalupas, Y. and Whitelaw, J. H., Interaction between sprays from multiple coaxial airblast atomizers, Journal of Fluids Engineering, Vol. 118 (1996), pp. 762-771. 
Hirt, C. W. and Nichols, B. D., Volume of fluid method for the dynamics of free boundaries, Journal of Computational Physics, Vol. 39 (1981), pp. 201-225.

Inamura, T., Tamura, H. and Sakamoto, H., Characteristics of liquid film and spray injected from swirl coaxial injector, Journal of Propulsion and Power, Vol. 19, No. 4 (2003), pp. 632-639.

Ishii, E., Ishikawa, M., Sukegawa, Y. and Yamada, H., Secondary-drop-breakup simulation integrated with fuel-breakup simulation near injector outlet, Journal of Fluids Engineering., Vol. 133 (2011).

Kobayashi, K., Atomizing characteristics of swirl injection nozzle, Transactions of the JSME, Vol. 19, No. 80 (1953), pp. 64-68 (in Japanese).

Miyamoto, T., Kobayashi, T. and Matsumoto, Y., Structure of sprays from an air-assist hollow-cone injector, SAE Technical Paper (1996), 960771.

Qian, J. and Law, C. K., Regimes of coalescence and separation in droplet collision, Journal of Fluid Mechanics, Vol. 331 (1997), pp. 59-80.

Rizk, N. K. and Lefebvre, A.H., Influence of liquid film thickness on airblast atomization, Journal of Engineering for Power, Vol. 102, No.3 (1980), pp. 706-710.

Rizk, N. K. and Lefebvre, A.H., Internal flow characteristics of simplex swirl atomizers, Journal of Propulsion and Power, Vol. 1, No. 3 (1985), pp. 193-199.

Samenfink, W., Albrodt, H., Frank, M., Gesk, M. and Melsheimer, A., Strategies to reduce HC-emissions during the cold starting of a port fuel injected gasoline engine, SAE Technical Paper (2003), 2003-01-0627.

Tani, Y., Mori, Y. and Mochizuki, K., Multiple-hole nozzle atomization for SI engines, SAE Paper(1999), 1999-01-0564.

Tani, Y., Okamoto, A., Inagaki, H. and Suzuki, T., Multiple hollow-cone like spray formation using plate type multi-hole nozzle, Proceedings of the 11th Symposium of Atomization (ILASS-Japan) (2002), pp. 94-97 (in Japanese).

Tani, Y., Iwamoto, M., Suzuki, T. and Inoue, Y., Multiple hollow-cone-like spray formation by controlling internal flow of multiple hole nozzles, Proceedings of ICLASS-2006 (2006), ICLASS06-068.

Yasukawa, Y. and Okamoto, Y., Fine atomization and low penetration fuel spray by using a multi-swirl nozzle for automobile engines, Proceedings of FEDSM2007 (2007), FEDSM2007-37013.

Yasukawa, Y., Okamoto, Y., Kobayashi, N., Saito, T. and Saruwatari, M., Multi-swirl type injector for port fuel injection gasoline engines, SAE Technical Paper (2014), 2014-01-1436. 